Harris, L. J. (1932). Lancet, 222, 103 ז.

Harrison, H. E. \& Harrison, H. C. (1951). F. biol. Chem. 188, 83 .

Hickman, K. C. D., Harris, P. L. \& Woodside, M. R. (1942). Nature, Lond., I50, 9 I.

Himsworth, H. P. \& Lindan, O. (r949). Nature, Lond., 163, 30.

Hohlweg, W. (1951). Klin. Wschr. 29, 193.

Hove, E. L. (1943). Science, 98, 433.

Hove, E. L. \& Harris, P. L. (1947). F. Nutr. 34, 57 I.

Hubbard, R. \& Wald, G. (1952). Congr. int. Biochim. Ir. Paris. Résumés des Communications, p. 213. Jacobi, H. P., Rosenblatt, S., Chappell, J. W. \& Morgulis, S. (1950). Arch. Biochem. 27, 9.

Jacobi, H. P., Rosenblatt, S., Wilder, V. M. \& Morgulis, S. (1950). Arch. Biochem. $27,19$.

Kalsbeek, F. \& van der Meer, C. (1950). Biochim. biophys. Acta 6, 135.

Mason, K. E. \& Ellison, E. T. (1935). F. Nutr. 9, 735.

Melville, R. S. \& Hummel, J. P. (195 r). F. biol. Chem. I9r, $3^{8} 3$.

Meunier, P., Ferrando, R., Jouanneteau, J. \& Thomas, G. (1949). Bull. Soc. Chim. biol., Paris, 31, I4I3.

Miller, W. H. \& Dessert, A. M. (1949). Ann. N.Y. Acad. Sci. 52, 167.

Moore, T. (1942). Biochem. F. 37, I12.

Moore, T. (1949). Ann. N.Y. Acad. Sci. 52, 206.

Moore, T. (1952). Experientia. (To be published, 1953.)

Moore, T., Sharman, I. M. \& Ward, R. J. (1952a). Congr. int. Biochim. Ir. Paris. Résumés des Communications, $p .220$.

Moore, T., Sharman, I. M. \& Ward, R. J. (1952b). Biochem. $\mathcal{7 . ~ 5 2 , ~ x i i . ~}$

Moore, T. \& Wang, Y. L. (1947). Brit. F. Nutr. I, 53.

Nicolaysen, R. (r937a). Biochem. F. 31, ro7.

Nicolaysen, R. (1937b). Biochem. F. 31, 122.

Schwarz, K. (1944). Hoppe-Seyl. Z. 281, rog.

Victor, J. (1934). Amer. Ұ. Physiol. 108, 229.

Wald, G. (1949). Science, 109, 482.

Zetterström, R. \& Ljunggren, M. (1951). Acta chem. scand. 5, 283.

\title{
The Mode of Action of Vitamin C
}

\author{
By Leslie J. Harris, Dunn Nutritional Laboratory, \\ University of Cambridge and Medical Research Council
}

I have a relatively easy task compared with the other contributors to this discussion, because there is less that can be said definitely about the mode of action of vitamin C. For some other water-soluble vitamins, such as vitamin $B_{6}$ and pantothenic acid, we can speak of specific coenzyme systems, each with its own clear biochemical role to play. But for vitamin $\mathrm{C}$ we have not yet reached this stage of knowledge. Indeed, in my view, the two most essential facts about vitamin $\mathrm{C}$ action, so far as present knowledge goes can be summed up under a couple of simple headings, as follows:

(a) Biochemical role of vitamin C. It is generally thought that the action of vitamin $\mathrm{C}$ must be linked in some way with its intense reducing action, which depends on the presence in its molecule of the characteristic ene-diol grouping. However, it has to be admitted that the exact biochemical role is still obscure. One of the few definitely established facts so far is that, in animal tissues, ascorbic acid can catalyse the oxidation of the aromatic amino-acid, tyrosine.

(b) Interpretation of the morphological effects of deficiency. The structural changes which can be seen microscopically in scurvy, for example in the teeth and 
in the bones, can be regarded as due fundamentally to an impairment of the functional activity of the formative cells.

But in seeking to reduce the whole problem to these two headings, I am perhaps endeavouring to escape too easily from my obligations. There does indeed exist a very considerable literature bearing on the topic of vitamin $\mathrm{C}$ action, either directly or indirectly. It would be easy to say that where knowledge is scanty there the literature is correspondingly bulky: but this would not be wholly fair. Much can be turned up that is suggestive, instructive, and indeed significant, in a study of this widely dispersed and voluminous bibliography.

The review which follows aims at being selective rather than exhaustive. To begin, it may be well to map out in advance the different sections in which $I$ propose to consider the problem.

(I) Morphological effects of deficiency. As scurvy was known long before the existence of any vitamin was suspected, it will be logical (for this and for other reasons) to deal first with the characteristic morphological manifestations seen in animals suffering from a deficiency, and to ask how these are to be explained.

(2) Chemical effects of deficiency. Secondly, we may inquire what specific chemical abnormalities are found in vitamin $\mathrm{C}$ deficiency in man and animals. As already mentioned, a disordered tyrosine metabolism seems one of the most important specific points yet brought to light.

(3) Vitamin C and animal physiology. Thirdly, we may refer to various other properties of vitamin $\mathrm{C}$ which are of interest from the point of view of animal physiology.

(4) Chemical reactions in vitro. Fourthly, allusion must be made to the numerous chemical reactions in vitro, in which it has been shown that vitamin $\mathrm{C}$ can intervene. How far are any of these significant for vitamin $\mathrm{C}$ action in the intact animal ?

(5) Plant physiology. Finally, we must turn to plant physiology, and inquire why vitamin $\mathrm{C}$ is present in such extraordinarily high concentration in some fruits and plants, and yet is almost absent from others. (And why is it present in some organs of the plant and not in others?) There seems no clear answer yet.

Then, also in the realm of plant physiology, there have been indications that vitamin $\mathrm{C}$ may be concerned in the catalytic oxidation of lactate to pyruvate, and in the triosephosphate system, as well as in the tyramine-quinone equilibrium; and we shall have occasion to return to these matters later (p. 139).

\section{Interpretation of morphological abnormalities in vitamin $C$ deficiency}

The first main section can be discussed under two separate subheadings: (a) collagen formation, and (b) function of formative cells.

\section{(a) Collagen formation}

It was shown by Wolbach \& Howe (1926) that a deficiency of vitamin C can result in a faulty formation of collagen, the intercellular cementing substance. From this, 
it has sometimes been argued that the primary defect in scurvy is an inadequate production and maintenance of collagen. However, objections have been raised to this view: for example Robertson (1950, $1952 a, b$ ) describes his experimental results as being ' in conflict with the broad generalization that ascorbic acid is necessary for the maintenance of collagen', although presumably it is needed during its formation.

\section{(b) Formative cells}

A wider general explanation of the structural defects seen in vitamin $\mathrm{C}$ deficiency has been put forward, which is that the vitamin is specifically needed for maintaining the normal functional activity of the various types of formative cells, such for example as the osteoblasts (the bone-producing cells), the odontoblasts (the dentine-producing cells), the ameloblasts (enamel-producing) and so on. In other words, according to this view the structural manifestations in scurvy can be regarded as due to an impairment in the function of such formative cells (Harris, 1934, 1935).

This explanation helps us to account for the remarkable changes in the structure of the teeth in scurvy in guinea-pigs, an early study of which had been made by Höjer (1924, 1926) and which were more systematically investigated by Fish \& Harris (1934). Among the new facts brought out in these studies with Fish was the fact that a deficiency of vitamin $C$ results in defective production not only of the dentine, as already known, but also of the enamel and of the cement, as well as of the alveolus.
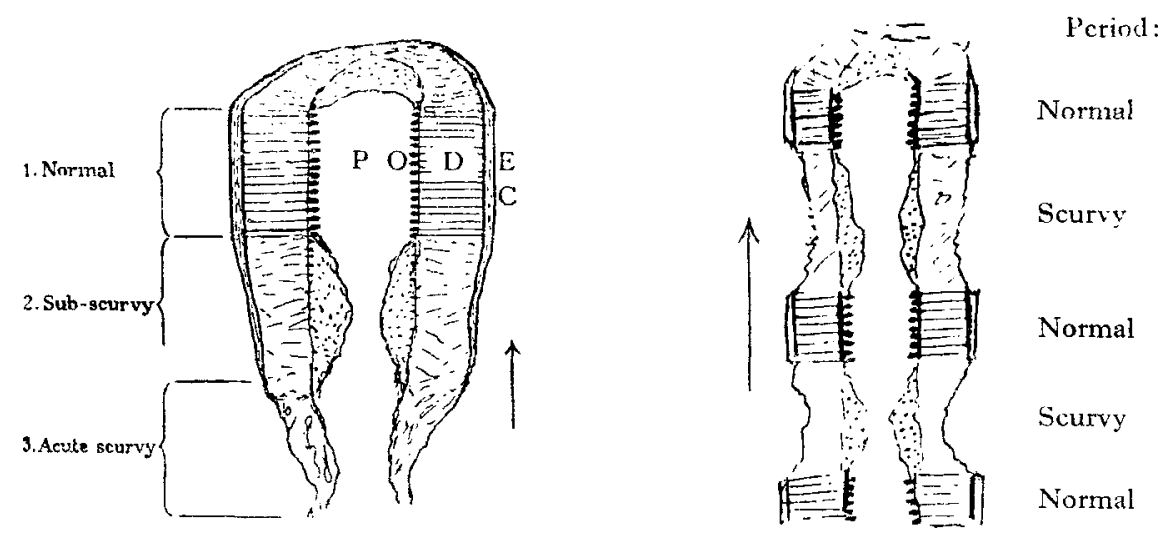

Fig. I. Effect of lack of vitamin C on tooth structure. (After Har ris, 1935.) Diagrammatical representation of a longitudinal section of the incisor tooth of a guinea-pig (growing continuously in direction of arrow) to show the effect of three successive diets in turn.

(I) Normal. With adequate vitamin C, the odontoblasts, or dentine-forming cells, $(\mathrm{O})$ are arrayed in orderly columns around the pulp chamber $(P)$, and produce regular tubular dentine (D).

(2) Partial deficiency. The odontoblasts become partly degenerated and are no longer able to produce normal tubular dentine. Some irregular dentine is formed and invades the pulp cavity.

(3) Severe deficiency. Odontoblasts completely degenerated. Little or no new dentine is formed. Similarly, new enamel (E) and cementum (C) are absent.

Fig. 2. Effect on tooth structure of intermittent scurvy and cures. Schematic diagram, longitudinal section of incisor tooth of guinea-pig. (Based on findings of Fish \& Harris, 1934.) 
Dental lesions in hyporitaminosis $C$. One phenomenon explicable, as I think, on the basis of the fore-mentioned theory is the fact that the dental abnormalities seen with a prolonged partial deficiency of vitamin $\mathrm{C}$ are in some respects more remarkable than those with a complete deficiency. This is illustrated in Figs. I and 2.

Bone lesions. Just as absence of vitamin C from the guinea-pig's diet results in cessation of new tooth formation, so also it results in a cessation of new bone formation (Fig. 3). Likewise in man, the most characteristic feature of infantile

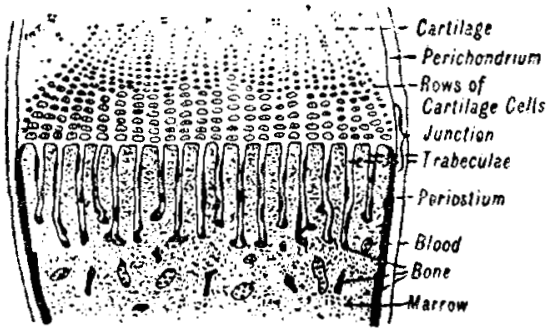

(1)

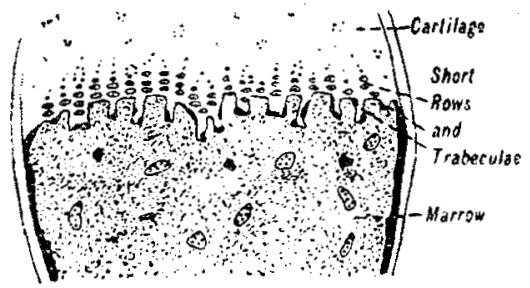

(3)

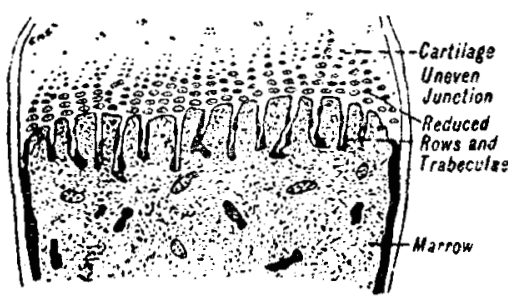

(2)

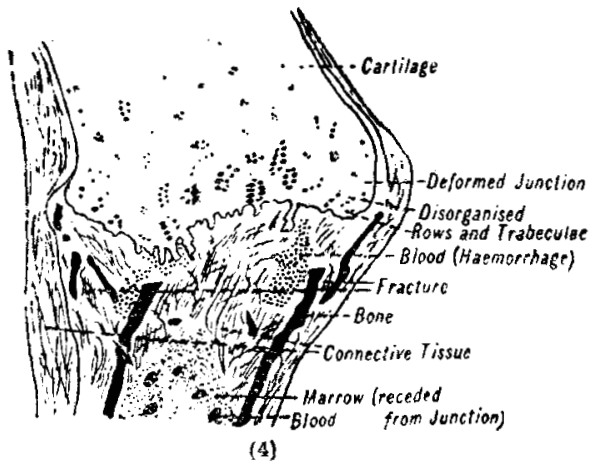

(4)

Fig. 3. Effect of scurvy on structure of bone. (After Delf \& Tozer, 1918.) Diagram of rib junct,on of guinea-pig: (1) Normal. (2) Incipient scurvy. (3) 'Definite' scurvy. (4) Acute scurvy.

scurvy is perhaps in the bones-namely the cessation of osteogenesis. Clearly, then, this too is in keeping with our general concept.

And furthermore, just as a prolonged partial deficiency of vitamin $\mathrm{C}$ may cause in guinea-pigs a continuous overgrowth of the imperfectly forming new dentine (as studied by Fish \& Harris), so in a somewhat corresponding manner there can occur, in some circumstances, a no less remarkable overgrowth of bony tissues (see studies on bone fractures in scurvy by Lexer, I939; Bourne, I942, I943, I944 $b$; Murray \& Kodicek I $949 a-c)$. I think that the explanation is the same: with a partial deficiency there results a partial failure of the normal function of the formative cells-the osteoblasts in this instance.

Wound healing. Again, the unsatisfactory healing of wounds observed in scurvy (Lanman \& Ingalls, I937; Taffel \& Harvey, 1938; Lauber \& Rosenfeld, I938; Crandon, Lund \& Dill, I940; Hunt, I94I; Bourne, I944a; Campbell, Ferguson \& 
Garry, 1950)-that is to say, the inadequate formation of the new tissues-is presumably amenable to an interpretation on these same lines.

Human applications. When describing the failure of normal tooth production resulting from a dietary shortage of vitamin $\mathrm{C}$, I was referring to observations on experimental guinea-pigs, and the question arises how far similar considerations apply to human subjects. For myself, I am inclined to believe that in the early years of life in the human infant (that is during the period of actual formation of the teeth) a relative deficiency of vitamin $\mathrm{C}$ might be expected to result in similar imperfections in tooth structure, which might well predispose to a liability to dental disease in later life.

In a recent survey, Follis, Park \& Jackson (1950) at the Johns Hopkins Hospital found microscopic evidence of scurvy to be present, post mortem, in a surprisingly high proportion of the infants they examined, among those in the bottle-fed group (namely $3 \mathrm{I} \%$ of the babies fed on cow's milk alone, between the $5^{\text {th }}$ and IIth months of age). I believe that it would be interesting to learn whether, in their cases, alongside these bony changes, there were also signs of dental abnormalities which could be attributed to the vitamin $\mathrm{C}$ deficiency.

Chemical interpretation of morphological changes. What I have been saying so far probably falls within the terms of reference of my own paper, the title of which is ' The Mode of Action of Vitamin C', but only barely within the terms of reference of the title of the symposium as a whole, 'The Role of Vitamins in Metabolic Processes'. The next question therefore to ask is, how far can these morphological effects of the deficiency be explained in chemical terms? It is not very helpful to say that the reason presumably why the cells fail to do their task of forming new tissues is because they are short of a necessary reducing principle, namely ascorbic acid, which they must have in order to carry on their normal activities.

We can however be a little more explicit in a different direction, and that is by contrasting the mode of action of vitamin $\mathrm{C}$ with that of vitamin $\mathrm{D}$-in relation to the bones. Whereas, in the prevention of rickets, vitamin $\mathrm{D}$ acts by promoting an adequate supply and deposition of calcium salts within the newly forming bone, in the prevention of scurvy, vitamin $\mathrm{C}$ on the other hand acts by promoting the actual formation, by the bone-producing cells, of the new bony tissue itself.

Vitamin $C$ in cell physiology. A suggestive finding, which we owe to Geoffrey Bourne and others, is that vitamin $\mathrm{C}$ present in the osteoblasts and other formative cells, is concentrated in the Golgi apparatus. This is demonstrated by chemical staining with silver nitrate. As Bourne (I94I) has written: 'It has been known for some time that, in scurvy, synthetic processes of cells are inhibited. . . The Golgi apparatus is recognized as a synthetic centre of the cell, and the presence in it of vitamin $\mathrm{C}$ during active synthesis raises the question as to the part that vitamin $\mathrm{C}$ could play in the synthesis of a wide variety of chemical substances. The most likely explanation is that, with increased cell metabolism, the synthetic products would be metabolized as rapidly as they are formed unless they were produced in a specially segregated, high reducing area of the cytoplasm'.

Vascular changes. Apart from the bony defects in the young animal, the other 
most characteristic feature of scurvy is the liability to haemorrhage. Here we are almost without any clue of explanation. Although it has been supposed that deficiency of vitamin $\mathrm{C}$ results in some weakening of the structure of the capillary walls, the truth is that we have really no adequate knowledge yet of the nature of the underlying changes in the blood vessels that are responsible.

\section{Chemical abnormalities in vitamin $C$ deficiency}

As already indicated, almost the only chemical change that can be regarded as at all specific, known to be associated with deficiency of vitamin $\mathrm{C}$, is the derangement in tyrosine metabolism-a phenomenon to which attention has been directed particularly by Sealock and his colleagues (Sealock, Perkinson \& Silberstein, 1940; Sealock \& Silberstein, I940; Lan \& Sealock, 1944).

\section{Tyrosine metabolism}

The known facts* can be summarized very briefly as follows:

In guinea-pigs with scurvy, the administration of L-tyrosine, or of phenylalanine, results in a large excretion of hydroxyphenol derivatives in their urine. This defect is remedied when ascorbic acid is restored to the diet.

The conclusion is that there is a defect of tyrosine metabolism in scurvy; this conclusion is borne out by experiments in vitro. In these it has been found that the oxidation of tyrosine proceeds more slowly in liver slices obtained from scorbutic animals than in those from normal animals. The addition of ascorbic acid to the scorbutic liver slices restores the oxidation.

In human subjects also, and in monkeys, it has likewise been shown that, in scurvy, there is a defective oxidation of tyrosine, given in the form of a test dose, as indicated by the excretion of a large proportion of hydroxyphenol derivatives.

There seems no escape then, from the conclusion that the metabolism of tyrosine in the liver depends, in some way, on the presence of ascorbic acid. This is an important finding, but just how that fits into the wider biochemical picture, and

\section{Table 1. Selected literature on tyrosine metabolism in vitamin $C$ deficiency}

In guinea-pigs:

Sealock, Perkinson \& Silberstein (1940)

Sealock \& Silberstein ( 1940$)$

Lan \& Sealock (1944)

Reinits (1950)

Painter \& Zilva (1950)
In man:

Levine, Marples \& Gordon (r939)

Rogers \& Gardner (1949)

In monkeys:

Salmon \& May (I950)

Woodruff (r95o)

helps to explain the biochemical action of the vitamin, needs further study. Indeed Painter \& Zilva (I950) would take the critical view 'that this interaction between L-ascorbic acid and L-tyrosine is a physiological response to an unusual situation and has no important bearing on normal nutrition'. 'They do concede

* For selected bibliography, see Table I. 
however that 'the part played by L-ascorbic acid is, nevertheless, of biochemical interest'.

There has been some question whether or not folic acid can partly replace ascorbic acid in correcting the abnormal excretion of tyrosine derivatives and we shall have to return to this substance, folic acid, again later.

\section{Other properties of vitamin $C$, in relation to animal physiology}

In order to consider in a little more detail some of the additional physiological interests of vitamin $\mathrm{C}$, it will be helpful to make somewhat more comprehensive lists of the effects both (a) of a deficiency of the vitamin (Table 2), and (b) of giving extra of it to animals (Table 3 ).

Table 2. Vitamin $C$ action. Observations on whole animals. I. Some recorded effects of deficiency in man or the guinea-pig or both

I. Haemorrhages

2. Defective bone and tooth structure

3. Ineffective wound healing (low tensile strength), abnormal repair of bone injuries

4. Fall in level of alkaline phosphatase in blood and osteoid

5. Secondary anaemia
6. Follicular hyperkeratosis

7. Cardiac lesions

8. Diminished activity of liver enzymes, e.g. esterase

9. Increased susceptibility to infection

Io. Increased fatigue (?)

Ir. Impaired adrenal function (?)

Various effects of deficiency. Of the different results of a deficiency enumerated in Table 2, nos. I-3 (haemorrhage; abnormalities in bones and teeth; defective wound repair) have already been discussed above. No. 4 (the fall observed in the level of alkaline phosphatase in the blood and the osteoid tissue) can presumably be explained as a consequence of the diminished production of the new osteoid itself. Nos. 5-7 (the occurrence of secondary anaemia, of follicular hyperkeratosis, and possibly of cardiac lesions) seem of variable occurrence, and probably of doubtful specificity-but regarding anaemia, see below, under the heading ' Folic acid'. The same applies to the various reports (e.g. Raabe, 1938; Harrer \& King, I94I) of a diminished activity of various enzymes in scurvy (no. 8). Two points (nos. 9 and ro, the liability to infection, and the relation to stress and adrenal function) will receive further consideration later.

Effects of increased intakes of vitamin $C$ (Table 3 ). A diuresis is produced by large doses of vitamin $\mathrm{C}$ (Table 3 , no. I), but there seems no adequate explanation of it yet; nor is there of the effects recorded for vitamin $\mathrm{C}$ in aiding some detoxication mechanisms (no. 2). The increased survival time induced by vitamin $\mathrm{C}$ in rats suffering from haemorrhage, or in rats or mice deprived of oxygen (nos. 3 and 4 ) can presumably be explained as a consequence of the effect of vitamin $\mathrm{C}$ in aiding tissue respiration. Other items in Table 3 are discussed below. 
Table 3. Vitamin $C$ action. Observations on whole animals. 2. Some effects recorded of increased vitamin $C$ intake

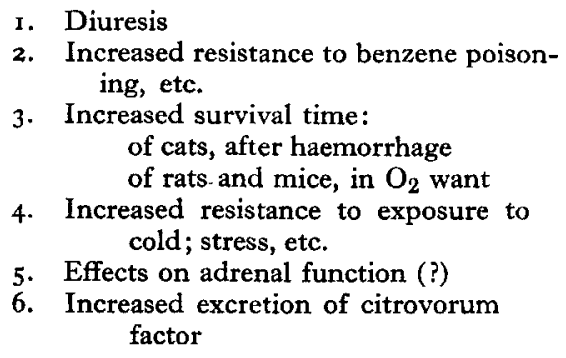

\section{Vitamin $C$ and folic acid}

About the relation between vitamin $\mathrm{C}$ and folic acid there is already a considerable literature (for literature on vitamin $\mathrm{C}$ in relation to folic acid, the following papers, among others, may be consulted: Welch, Nichol, Anker \& Boehne, I95I; Hill \& Scott, 1952; Schwartz \& Williams, 1952; Anonymous, 1952), but the essential point can, I think, be put in a single sentence as follows: vitamin $\mathrm{C}$ appears to be concerned, in an enzyme system, in converting folic acid (pteroylglutamic acid) to folinic acid (or the so-called 'citrovorum factor') --and perhaps also in releasing this same folinic acid from some bound or 'conjugated' form.

The 'citrovorum factor' is a biologically active derivative of folic acid. It is the form which is excreted in the urine when folic acid is administered by mouth, to rats or to man. It was given its name, the ' citrovorum factor', because it was found to be needed as a growth factor by the micro-organism Leuconostoc citrovorum. Folic acid itself is inactive for this particular micro-organism.

The foregoing explanation about the role of vitamin $\mathrm{C}$ suffices to explain many known observations, e.g. why, when more vitamin $\mathrm{C}$ is given to an animal by mouth, there follows an increased excretion of folinic acid in the urine, whereas in scurvy there is a lowered excretion of folinic acid. It should also, in time, give us a fuller understanding of the existence, which has been suspected for many years, of some kind of a relationship between scurvy and anaemia.

\section{Vitamin $C$ and infection}

We are not yet very near any real understanding of the connexion between vitamin $\mathrm{C}$ and resistance to infection. Among the more important known facts are the following:

(I) A deficiency of vitamin $\mathrm{C}$ results, both in man and in guinea-pigs, in a greatly increased susceptibility to infection. (For example, anyone who works with guineapigs experimentally knows that it is difficult to do a curative assay test for vitamin $\mathrm{C}$ as compared with a preventive test, on a guinea-pig, because the animal is liable to become infected, when scorbutic, before the curative dose can be given.) 
(2) In infectious ailments there is a lowered vitamin $\mathrm{C}$ status, as indicated by a diminished degree of saturation on test-dosing, and by a lowered vitamin $\mathrm{C}$ content of the tissues (Abbasy, Harris \& Ellman, I937; Harris, Passmore \& Pagel, 1937). This is notably so in pulmonary tuberculosis, where the vitamin C 'reserves' are decreased to a remarkable degree as compared with those of control subjects on the same vitamin $\mathrm{C}$ intake. These facts suggest that there is an increased use of the vitamin in fighting infection, or perhaps there is an increased wastage of it.

In trying to think of an explanation of why the deficient animal is so liable to get infected, it is perhaps not too fanciful to suppose that in the absence of vitamin $\mathrm{C}$ there may result a faulty production of antibodies, corresponding to the general failure to produce new tissue by the formative cells.

\section{Vitamin $C$ and adrenal function}

It is a remarkable fact that although the adrenal cortex was the tissue first used by Szent-Györgyi (I928) for his pioneer studies on 'hexuronic acid' (later to be identified with vitamin $\mathrm{C}$ ), and although subsequent quantitative assays showed that vitamin $\mathrm{C}$ is present in remarkably high concentrations, not only in the adrenal cortex (Harris \& Ray, 1932, 1933a) but also in the medulla (Harris \& Ray, $1933^{b}$ ) - nevertheless we are still without any real understanding of the vitamin C-adrenal relationship.

An additional suggestive fact is that it has been repeatedly claimed that vitamin $\mathrm{C}$ function, e.g. the vitamin $C$ requirement, is related in some way to adrenal activity, or is affected by exposure to stress, cold, etc. (cf. review by Pirani, 1952; and Anonymous, 1950). It must be admitted that much of this literature is confusing and often contradictory.

More clearly established is the fact that administration of ACTH causes a transient fall in the concentration of ascorbic acid in the adrenal (Sayers, Sayers, Lewis \& Long, 1944), and indeed this phenomenon is used as the basis for a standard method for the assay of the hormone. My colleagues and I (Bland, Constable, Harris \& Hughes, 1952a, $b$; Hughes, Harris, Constable \& Bland, 1952) have tried to follow up this question, by seeing whether (as we expected) the continuous administration of ACTH to guinea-pigs would not produce some cumulative effect on their vitamin $\mathrm{C}$ metabolism. To our surprise our results have been substantially negative-in the sense that the ACTH had no important effect on vitamin C metabolism as a whole. The only consolation was an equally unexpected finding, that the administration of ACTH, while not profoundly affecting the vitamin $\mathrm{C}$ relations, did in the guinea-pig give rise to a remarkable and continuous increase in the weight of the liver (Fig. 4). We have seen this effect on the liver weight, so far only in guinea-pigs, and not, under the conditions of our trials, with the other species so far examined. Whether this is due to the fact that the guinea-pig is unique in needing vitamin $\mathrm{C}$ whereas all the other species do not, we are not yet in a position to say. (But see note added at proof stage, p. I 42.) 


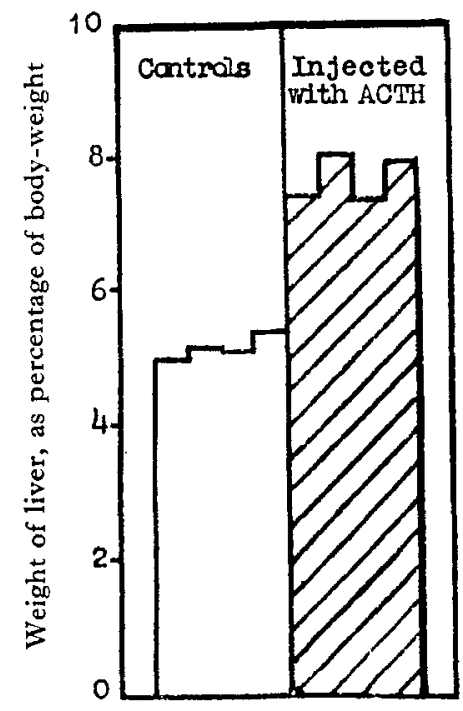

(I) Weights of livers of individual guinea-pigs after Io days' injections.

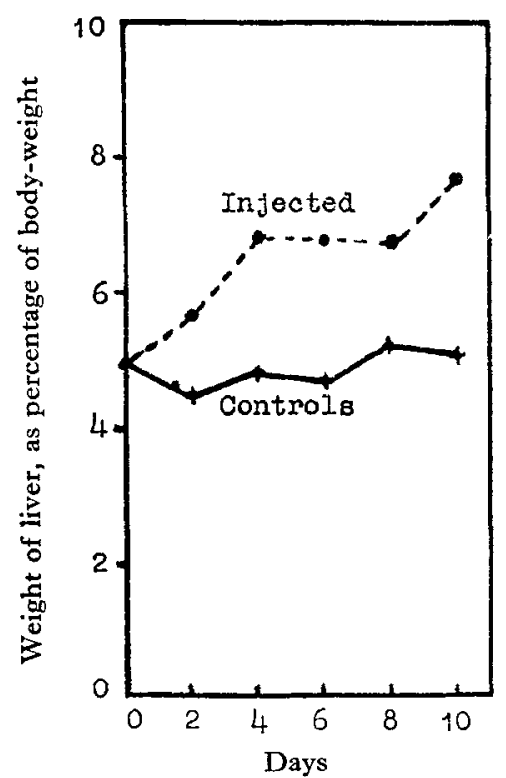

(2) Increase in average weight of livers of guinea-pigs on injection with ACTH over ro-day period, as compared with controls.

Fig. 4. Increase in weight of liver of guinea-pigs injected with ACTH (2 mg Armour Standard, L.A.IA., four times daily).

\section{Chemical reactions controlled by vitamin $C$ in vitro}

Vitamin $\mathrm{C}$ can participate in vitro in various types of chemical reactions, e.g.

(a) in oxidation-reduction reactions,

(b) in the activation of certain enzyme systems, and

(c) in relation to folic acid.

It will be best here to concentrate our attention simply on the reactions of class (a) (oxidation-reduction).

As to class (b), it will suffice to remark that the effect of vitamin $\mathrm{C}$ in accelerating some enzyme reactions seems to lack specificity, in the sense that the vitamin can in some instances be replaced for this purpose by various other reducing agents; also it is doubtful how far such an action can be of significance for the specific effect of vitamin $\mathrm{C}$ seen in vivo, in preventing scurvy.

The interaction between vitamin $\mathrm{C}$ and folic acid has already been discussed in the previous section, and need not be reviewed afresh here.

\section{Vitamin $C$ in oxidation-reduction reactions}

The most remarkable feature, chemically, of vitamin $\mathrm{C}$ is its reversible oxidation to dehydroascorbic acid, with the liberation of two hydrogen atoms, and it is reasonable to suppose that it functions biochemically as a hydrogen carrier. 


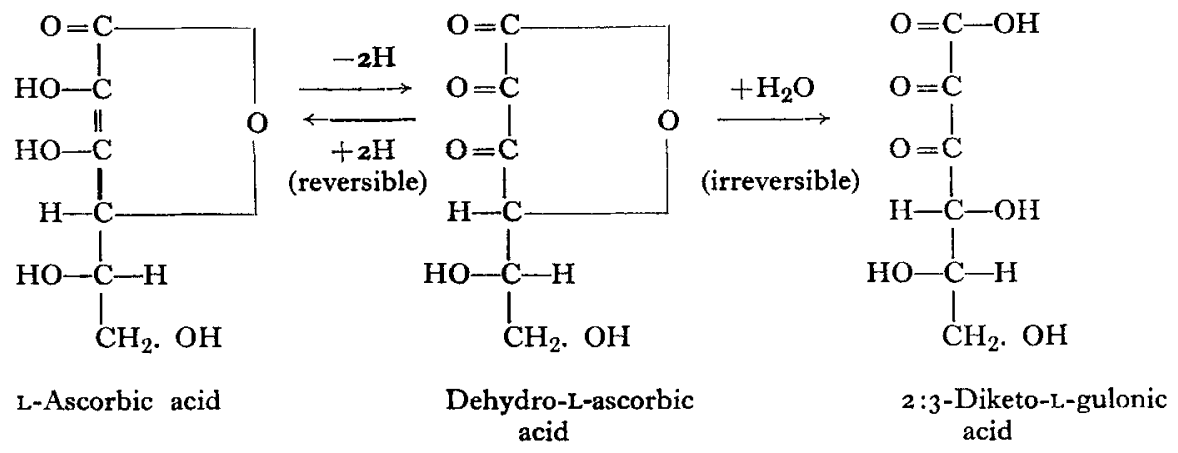

Szent-Györgyi (1938) in his Nobel-Prize Vortrag (Table 4) put forward a theory of vitamin $\mathrm{C}$ action, according to which it was involved as a hydrogen carrier in a system alongside flavones ('vitamin $\mathrm{P}$ '), ascorbic oxidase and $\mathrm{H}_{2} \mathrm{O}_{2}$ peroxidase.

Table 4. Theory of vitamin $C$ action (Szent-Gyorgyi, 1938)

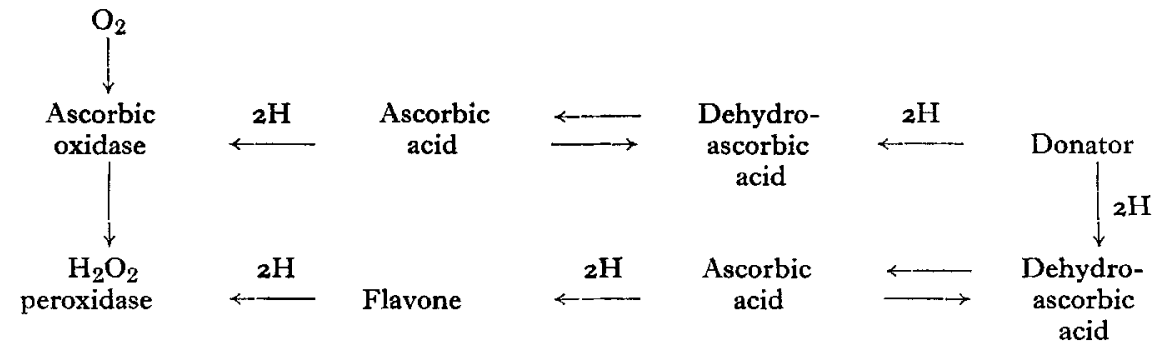

Experimentally, the reducing action of vitamin $\mathrm{C}$ has been studied in numerous ways, some of the more notable including:

(I) the reaction with oxidation-reduction indicators, such as indophenol, and numerous other reducible substances, many of them obviously not of special biological significance;

(2) the oxidation of vitamin $\mathrm{C}$ under the catalytic influence of ascorbic oxidase, the first stage being the reversible oxidation to dehydroascorbic acid, and the second the irreversible change to diketogulonic acid and more oxidized products ;

(3) the system containing glutathione, in addition to ascorbic acid and ascorbic oxidase, in which, as shown by Hopkins and his colleagues, glutathione becomes vicariously oxidized and thereby spares the vitamin (Hopkins \& Morgan, I936; Crook \& Hopkins, 1938; Crook, I94I);

(4) the coupled oxidation of haemoglobin and ascorbic acid studied by Lemberg, Legge \& Lockwood (1939, 1941 $a, b$ ).

Biological significance of oxidation reactions. It is hard to escape the conviction that the interaction between ascorbic acid and glutathione must be of some biological consequence. (Both substances occur in considerable quantities in numerous tissues, although admittedly they are virtually absent from many others.) What 
strengthens this conviction is the fact, demonstrated by Pfankuch (1934) and by Hopkins and his school (Hopkins \& Morgan, I936; Crook \& Hopkins, I938; Crook, 194I), that in the reversible equilibium between ascorbic acid and dehydroascorbic acid, glutathione has the remarkable property of being able to reverse the oxidation, and so to reconvert reversibly oxidized dehydroascorbic acid back to ascorbic acid, which is then free to act once more as a hydrogen carrier-and, perhaps, so on, ad infinitum.

Further evidence of the reality of some such oxidative role of vitamin $\mathrm{C}$ in vivo, is that the tissues from scorbutic guinea-pigs do exhibit a diminished oxidative capacity in vitro, and that this can then be restored by the addition of ascorbic acid to the preparation (Harrison, I933; Quastel \& Wheatley, r934; Kellie \& Zilva, I94I; Snow \& Zilva, 194I). This fact seems to establish beyond doubt the truth of the concept that a deficiency of ascorbic acid does in fact cause a defective tissue respiration in the deficient animal.

Any more detailed discussion of the chemical role of vitamin $\mathrm{C}$ in oxidation reactions, or in enzyme systems, would perhaps be out of place in this present (nutritional) context, and reference may instead be made to review articles, such as those in Respiratory Enzymes (edited by Lardy, 1949), and in Annual Reviews of Biochemistry.

\section{Vitamin $C$ action in plant biochemistry}

I have previously referred to our present inability to explain why vitamin $\mathrm{C}$ should be present in such high concentrations in some plant sources (e.g. in black currants, watercress or bananas) and be almost absent from others (e.g. mushrooms, celery or pears). Speaking teleologically, we are largely ignorant of the chemical purpose of vitamin $\mathrm{C}$ in the plant kingdom, although suggestive studies have been made within the last few years of the influence of vitamin $\mathrm{C}$ on such reactions as:

(a) the catalytic oxidation of lactate to pyruvate (James \& Cragg, 1943),

(b) in the triosephosphate system (James, Heard \& James, 1944), and

(c) in the tyramine-quinone equilibium (Miller, Mallette, Roth \& Dawson, 1944).

\section{Some outstanding questions}

It will be well to conclude by emphasizing the extent of our ignorance, rather than by giving any further details of what has already been discovered. Among other lacunae are the following.

(r) We have, up to now, no real knowledge of the chemical steps by which ascorbic acid is synthesized in the animal body (that is, by species other than primates and guinea-pigs). All that can be said is that glucose is thought to act as a precursor, since administration to rats of glucose 'labelled' with ${ }^{14} \mathrm{C}$ is followed by the excretion of 'labelled' ascorbic acid in their urine (Horowitz, Doerschuk $\&$ King, 1952).

(2) Another wide gap in our understanding is that there is no certainty about 
the site in the body where the synthesis of vitamin C occurs-although it may well be in numerous tissues in the body and not localized. Hopkins (1934) supposed it to be in the intestine, but Zilva (1935) questioned that conclusion. Again, in the plant kingdom we are equally without information about which cells in the organism are responsible for the synthesis; but apparently, it is again throughout the plant and not specialized locally.

Finally, what is the reason why vitamin $\mathrm{C}$ should be found in such relatively large quantities in an apparently diverse set of organs as, for example, the adrenal cortex and medulla, the eye lens and the vitreous and aqueous humour or the white blood cells, and by contrast in such relatively meagre amounts in others, e.g. the red cells, the muscles, the brain and the pancreas? Until we know the answers to these questions we cannot pretend that our knowledge of vitamin $\mathrm{C}$ action is in a very complete state.

\section{SUMMARY}

Probably the most notable property of vitamin $\mathrm{C}$ chemically is its intense reducing activity, depending on the presence in its molecule of the characteristic ene-diol grouping. Because of this, it has generally been assumed that the biological action of the vitamin depends on its intervening at some point in oxidation-reduction reactions within the body. Nevertheless, it has to be admitted that we are still without any real knowledge about the precise role (or roles) of the vitamin in chemical systems in the living organism.

One of the few significant facts which has so far emerged is that in animal tissues ascorbic acid is able to catalyse the oxidation of the aromatic amino-acid, tyrosine.

Morphologically, the structural abnormalities seen in scurvy, e.g. in teeth and bones, can be attributed to an impairment in the functional activity of the formative cells.

Among other matters discussed in the course of the review, are the connexions between vitamin $\mathrm{C}$ and the following: folic-acid metabolism, adrenal function, infectivity, various oxidation-reduction systems, enzyme activation, and some aspects of plant physiology.

\section{REFERENCES}

Abbasy, M. A. (1937). Biochem. F. 31, 339.

Abbasy, M. A., Harris, L. J. \& Ellman, P. (1937). Lancet 233, 18r.

Anonymous (1950). Nutr. Rev. 8, 52.

Anonymous (1952). Nutr. Rev. ro, 40.

Bland, M. N., Constable, B. J., Harris, L. J. \& Hughes, R. E. (1952a). Biochem. F. r8, iv.

Bland, M. N., Constable, B. J., Harris, L. J. \& Hughes, R. E. (1952b). Congr. int. Biochim. 1I. Paris. Résumés des Communications, p. 325.

Bourne, G. H. (1941). F. Physiol. 99, 9P.

Bourne, G. H. (1942). Quart. F. exp. Physiol 31, 3 I9.

Bourne, G. H. (1943). F. Physiol. 102, 319.

Bourne, G. H. (1944a). Lancet, 246, 688.

Bourne, G. H. (1944b). Proc. R. Soc. Med. 37, 275 .

Campbell, F. W., Ferguson, I. D. \& Garry, R. C. (1950). Brit. F. Nutr. 4, 32. 
Crandon, J. H., Lund, C. C. \& Dill, D. B. (1940). New Engl. F. Med. 223, 353.

Crook, E. M. (I94I). Biochem. F. 35, 226.

Crook, E. M. \& Hopkins, F. G. (1938). Biochem. F. 32, 1356.

Delf, E. M. \& Tozer, F. M. (1918). Biochem. F. 12, 416.

Edman, B. (1947). Acta pharm. tox., Kbh., 3, 26I.

Fish, E. W. \& Harris, L. J. (r934). Phil. Trans. B. 223, 489.

Follis, R. H., Park, E. A. \& Jackson, D. (1950). Fohns Hopk. Hosp. Bull. 87, 569.

Forssman, S. \& Frykholm, K. C. (1947). Acta med. scand. 128, 256.

Friemann, W. (1936). Arch. Gewerbepath. Gewerbehyg. 7, 278.

Harrer, C. J. \& King, C. G. (1941). F. biol. Chem. 138, 111.

Harris, L. J. (r934). Quoted by Fish, E. W. \& Harris, L. J. (1934). Phil. Trans. B. 223, 489.

Harris, L. J. (1935). Vitamins in Theory and Practice, ist ed. Cambridge: University Press.

Harris, L. J., Passmore, R. \& Pagel, W. (1937). Lancet 233, 183.

Harris, L. J. \& Ray, S, N. (1932). Biochem. F. 26, 2067.

Harris, L. J. \& Ray, S. N. (1933a). Biochem. F. 27, 303.

Harris, L. J. \& Ray, S. N. (1933b). Biochem. F. 27, 2006.

Harrison, D. C. (1933). Biochem. F. 27, 1 501 .

Hill, C. H. \& Scott, M. L. (1952). Ұ. biol. Chem. 196, 195.

Höjer, J. A. (1924). Acta paediat., Stockh., 3 (suppl.), p. 34.

Höjer, J. A. (1926). Brit. F. exp. Path. 7, 356.

Hopkins, F. G. (1934). Chem. E Ind. 53, 874.

Hopkins, F. G. \& Morgan, E. J. (1936). Biochem. F. 30, 1446 ,

Horowitz, H. H., Doerschuk, A. P. \& King, C. G. (I952). F. biol. Chem. r99. 193.

Hughes, R. E., Harris, L. J., Constable, B. J. \& Bland, M. N. (1952). Biochem. 7 . 18, iv.

Hunt, A. H. (194I). Brit. F. Surg. 28, 436.

James, W. O., \& Cragg, J. M. (1943). New Phytol. 42, 28.

James, W. O., Heard, C. R. C. \& James, J. M. (1944). New Phytol. 43, 62.

Kellie, A. E. \& Zilva, S. S. (1941). Biochem. F. 35, 783.

Lan, T. H. \& Sealock, R. R. (1 944$)$. F. biol. Chem. r55, 483.

Lanman, T. H. \& Ingalls, T. H. (1937), Ann. Surg. 105, 616.

Lardy, H. A. [editor] (1949). Respiratory Enzymes. Minneapolis, Minn.: Burgess Publishing Co.

Lauber, H. J. \& Rosenfeld, W. (1938). Klin. Wschr. 17, 1587.

Lemberg, R., Legge, J. W. \& Lockwood, W. H. (1939). Biochem. F. 33, 754.

Lemberg, R., Legge, J. W. \& Lockwood, W. H. (1941a). Biochem. F. 35, 328.

Lemberg, R., Legge, J. W. \& Lockwood, W. H. (1941b). Biochem. F. 35, 339.

Levine, S. Z., Marples, E. \& Gordon, H. H. (1939). Science, 90, 620.

Lexer, E. W. (1939). Arch. klin. Chir. 195, 611.

Lucas, B. G. B. (194I). Quoted by Peterson, J. M. (194I). Nature, Lond., 148, 84.

Meyer, A. (1937). Z. Vitaminforsch. 6, 83.

Miller, W. H., Mallette, M. F., Roth, L. J. \& Dawson, C. R. (1944). F. Amer, chem. Soc. 66, 514.

Murray, P. D. F. \& Kodicek, E. (1949a). F. Anat., Lond., 83, 158.

Murray, P. D. F. \& Kodicek, E. (1949b) $\mathscr{7}$. Anat., Lond., 83, 205.

Murray, P. D. F. \& Kodicek, E. (1949c) F. Anat., Lond., 83, 285.

Painter, H. A. \& Zilva, S. S. (1950) Biochem. F. 46, 542.

Pfankuch, E. (1934). Naturwissenschaften, 22, 821 .

Pirani, C. L. (1952). Metabolism, I, 197.

Quastel, J. H. \& Wheatley, A. H. M. (1934). Biochem. $\mathcal{F . ~ 2 8 , ~ 1 0 1 4 . ~}$

Raabe, S. (1938). Biochem. Z. 299, 141.

Reinits, K. G. (1950). F. biol. Chem. 182, I I.

Roberston, W. van B. (1950). F. biol. Chem. 187, 673.

Robertson, W. van B. (1952a). F. biol. Chem. 196, 403 .

Robertson, W. van B. (1952b). Ұ. biol. Chem. 197, 495.

Rogers, W. F. \& Gardner, F. H. (1949). F. Lab. clin. Med. 34, I491.

Salmon, R. J. \& May, C. D. (r950). F. Lab. clin. Med. 36, 59 r.

Sayers, G., Sayers, M. A., Lewis, H. L. \& Long, C. N. H. (1944). Proc. Soc. exp. Biol., N.Y., 55, 238.

Schwartz, M. A. \& Williams, J. N. (1952). F. biol. Chem. 194, 7 I 1 .

Sealock, R. R., Perkinson, J. D. \& Silberstein, H. E. (1940). F. biol. Chem. r33, lxxxvii.

Sealock, R. R. \& Silberstein, H. E. (1940). F. biol. Chem. 135, 25 I.

Snow, G. A. \& Zilva, S. S. (1941). Biochem. F. 35, 878 .

Stewart, C. P., Learmonth, J. R. \& Pollock, G. A. (194I). Lancet, 240, 81 8.

Szent-Györgyi, A. (1928). Biochem. F. 22, 1387.

Szent-Györgyi, A. (1938). Nobel-Vortrag gehalten am II Dez. 1937 am Karolinischen MedicoChirurgischen Institut zu Stockholm, Stockholm: P.A. Norstedt and Söner. 
Taffel, M. \& Harvey, S. C. (1938). Proc. Soc, exp. Biol., N.Y., 38, $5^{18 .}$

Welch, A. D., Nichol, C. A., Anker, R. M. \& Boehne, J. W. (195I). F. Pharmacol. 103, 403.

Wolbach, S. B. \& Howe, P. R. (1926). Arch. Path. (Lab. Med.) I, I.

Woodruff, C. W. (1950). F. Lab. clin. Med. 36, 640 .

Zilva, S. S. (1935). Biochem. F. 29, roo.

Note added to proof, 14.2.53. The massive increase in liver weight after continuous administration of ACTH (see p. 136) has now been found to occur in at least one other species as well as the guinea-pig, namely in the rabbit. The enlargement is associated with an increase in the volume of the cytoplasm of the liver cells ; in the initial stages there is an increase in the glycogen and water in the liver, and later a gradual rise in protein also. Cortisone produces the same effect, and to an even greater degree. There is no evidence that the species difference is related to the vitamin $\mathrm{C}$ requirement. 